\title{
Acute Renal Failure and Seizure following Multiple Wasp Stings: A Case Report
}

\author{
Kumar MK' ${ }^{1}$, Thakur SN² \\ ${ }^{1}$ Dr. Mani Kant Kumar, MBBS, MD, Assistant Professor, ${ }^{2}$ Dr. SN Thakur, MBBS, MD, Professor and HOD. Both from the \\ Department of Paediatrics, Narayan Medical College and Hospital, Jamuhar, Sasaram, Rohtas, Bihar, India.
}

Address for correspondence: Dr. Mani Kant Kumar, E-mail: manikant7@yahoo.com

\begin{abstract}
Wasps and bees descend from order Hymenoptera. All social wasps belong to family Vespidae. Their stings are not usually life threatening, causing mainly local reactions and rarely anaphylaxis and serious systemic manifestations. Though a few stings cause no major problems, multiple stings can cause serious effects like massive hemolysis, acute renal failure, encephalopathy, multiorgan dysfunction. We report a six years boy with acute renal failure and seizure following multiple wasp stings.
\end{abstract}

Key words: Multiple wasp stings, Acute renal failure, Hymenoptera

\section{Introduction}

ymenoptera are social creatures that typically Isting following provocation. The insect Order Hymenoptera consists of Apidae family (Honeybees and Bumblebees), Vespidae family (Yellow jackets, hornets and wasps) and Formicidae family (ants). Bee and wasp envenomations are the most widely documented arthropod exposures in USA, with 4081 pediatric exposures and one death reported to poison control centres in 2005'. Although most common forms of toxicity are local and mild systemic allergic reactions but serious reactions such as hemolysis, acute renal failure, rhabdomyolysis, neuritis, encephalopathy and serum sickness are also rarely reported ${ }^{2}$. We report a case of a six year boy with acute renal failure, seizure and hemolysis following multiple wasp stings and who survived after appropriate management.

\section{The Case}

A six years old boy was attacked by a swarm of wasps 3 days back while playing with a box in the attic of their house, in which there was a hive. He suffered multiple stings over scalp, neck and arms. Initially child was treated by local practitioner with parenteral antihistamines and hydrocortisone with symptomatic relief. The following day child developed red colored urine with progressively decreasing urine output, swelling over face and yellowish discoloration of the eyes. On the third day the patient developed anuria and was referred for treatment in an intensive care setup. There was no history of difficulty in breathing, bleeding from any site, seizure and altered sensorium. On admission while in the emergency room, he was conscious, alert; had jaundice; mild pallor, facial puffiness and pitting edema over the scalp and limbs with multiple erythematous necrosed sting marks on the scalp, neck and arms. Sting marks were covered by scab, surrounded by erythema, and they were indurated and tender (Figure 1). Pulse rate was 102 per minute, respiratory rate 28 per minute and blood pressure $126 / 84 \mathrm{~mm}$ of $\mathrm{Hg}$. liver was palpable $3 \mathrm{~cm}$ below the right costal margin and rest of the systemic examination were unremarkable.

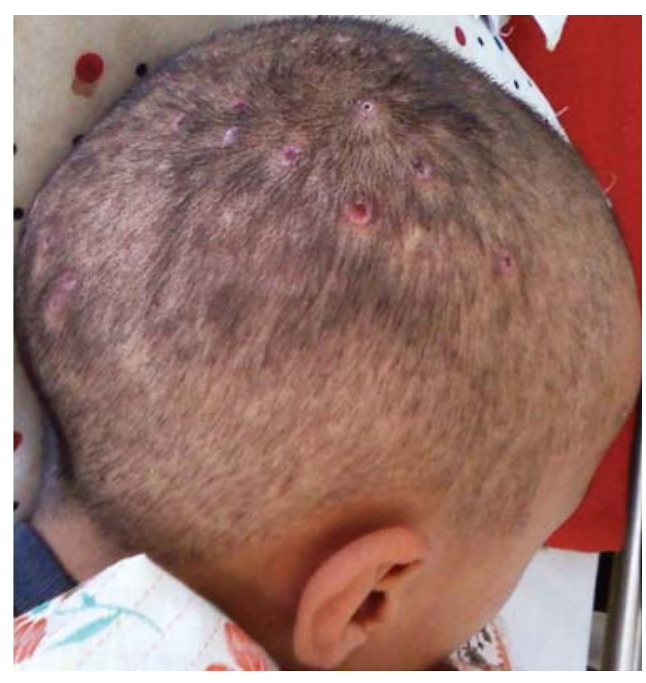

Fig 1: Photograph showing multiple necrosed erythmatous stings mark over scalp in the affected child. 
Treatment was started with antibiotics (I.V Ceftriaxone $100 \mathrm{mg} / \mathrm{kg} / \mathrm{d}$ ), antihistaminics (I.V.Pheniramine $0.5 \mathrm{mg} / \mathrm{kg} / \mathrm{d}$ ) and steroids (I.V.Dexamethasone $0.15 \mathrm{mg} / \mathrm{kg} /$ dose 6 hourly) and then the patient was shifted to paediatric intensive care unit. Initial investigations is as per Table 1.

Table 1: Initial Investigations.

\begin{tabular}{|c|l|c|}
\hline S. No. & Investigation & Value \\
\hline 1. & $\mathrm{Hb}$ & $8.5 \mathrm{gm} / \%$ \\
\hline 2. & $\mathrm{TLC}$ & $14,200 \mathrm{~mm} 3$ \\
\hline 3. & $\mathrm{DLC}$ & $\mathrm{P} 78, \mathrm{~L} 19, \mathrm{M} 2, \mathrm{E} 1$. \\
\hline 4. & Platelets & $2,31,000 \mathrm{~mm} 3$ \\
\hline 5. & Urea & $182 \mathrm{mg} \%$ \\
\hline 6. & Creatinine & $4.6 \mathrm{mg} \%$ \\
\hline 7. & Na & $136 \mathrm{mEq} / \mathrm{L}$ \\
\hline 8. & $\mathrm{~K}$ & $5.1 \mathrm{mEq} / \mathrm{L}$ \\
\hline 9. & Blood Glucose & $75 \mathrm{mg} \%$ \\
\hline
\end{tabular}

The following day, the child became irritable and his investigations are as shown in Table 2.

Table 2: Follow up Investigations

\begin{tabular}{|c|c|c|}
\hline S. No. & Investigation & Value \\
\hline 1. & $\mathrm{Hb}$ & $7.5 \mathrm{gm} / \%$ \\
\hline 2. & TLC & $16,700 \mathrm{~mm} 3$ \\
\hline 3. & DLC & P82, L14, M2, E2. \\
\hline 4. & Platelets & $2,10,000 \mathrm{~mm} 3$ \\
\hline 5. & ESR & $20 \mathrm{~mm}$ in $1 \mathrm{st}$ Hour \\
\hline 6. & Reticulocyte Count & $6 \%$ \\
\hline 7. & Total Serum Bilirubin & $9.8 \mathrm{mg} \%$ \\
\hline 8. & Direct: Indirect Bilirubin & 4.2:5.6 \\
\hline 9. & SGOT & $1648 \mathrm{U} / \mathrm{L}$ \\
\hline 10. & SGPT & $1562 \mathrm{U} / \mathrm{L}$ \\
\hline 11. & Alkaline Phosphatase & $784 \mathrm{IU} / \mathrm{L}$ \\
\hline 12. & Serun Protein & $5.6 \mathrm{gm} \%$ \\
\hline 13. & Albumin: Globulin & 2.7:2.9 \\
\hline 14. & Creatinine & $6.8 \mathrm{mg} \%$ \\
\hline 15. & Urea & $386 \mathrm{mg} \%$ \\
\hline 16. & $\mathrm{Na}$ & $132 \mathrm{mEq} / \mathrm{L}$ \\
\hline 17. & $\mathrm{~K}$ & $6.2 \mathrm{mEq} / \mathrm{L}$ \\
\hline 18. & Blood Glucose & $75 \mathrm{mg} \%$ \\
\hline 19. & Chloride & $98 \mathrm{mmol} / \mathrm{L}$ \\
\hline 20. & LDH & $758 \mathrm{U} / \mathrm{L}$ \\
\hline 21. & Prothrombin Time & $\begin{array}{c}\text { T: } 16 \text { and C: } 15 \\
\text { (INR:1.1) }\end{array}$ \\
\hline 22. & APTT & T: 28 and C: 26 \\
\hline 23. & Peripheral Blood Smear & \begin{tabular}{|l} 
Features of \\
Haemolysis \\
\end{tabular} \\
\hline 24. & Urine examination & $\begin{array}{l}\text { RBCs: Plenty, RBC } \\
\text { Casts, Protein 2+ }\end{array}$ \\
\hline
\end{tabular}

\begin{tabular}{|c|l|l|}
\hline 25. & USG Abdomen & $\begin{array}{l}\text { Hepatomegaly, } \\
\text { Raised renal cortical } \\
\text { echogenesity and } \\
\text { accentuated cortico } \\
\text { medullary density. }\end{array}$ \\
\hline 26. & Chest X-Ray & NAD \\
\hline
\end{tabular}

The child was managed on the line of acute renal failure (ARF) and peritoneal dialysis (PD) was carried out on the 2 nd day of admission; post PD (36 cycles), his serum urea and serum creatinine were $298 \mathrm{mg} /$ $\mathrm{dl}$ and $5.8 \mathrm{mg} / \mathrm{dl}$ respectively. On $3^{\text {rd }}$ day of admission he developed one episode of generalized tonicclonic seizure which was controlled with IV Diazepam followed by IV Phenytoin as per protocol without further recurrence. Metabolic workup for seizure and his CSF Examination were normal. Second PD was performed on the 4th day of admission. Post 2nd PD (40 cycles), serum urea and serum creatinine levels came down to $235 \mathrm{mg} / \mathrm{dl}$ and $5.0 \mathrm{mg} / \mathrm{dl}$ respectively (5th day). Third PD was performed on day $6^{\text {th }}$ of admission and after 3 rd PD (36 cycles) his serum urea and creatinine levels were 186 and 3.5 respectively. On $5^{\text {th }}$ day of admission he started passing urine approximately @ 0.5 ml $/ \mathrm{kg} /$ hour which was progressively increased to more than $1 \mathrm{ml} /$ $\mathrm{kg} / \mathrm{hour}$ on day $7^{\text {th }}$ of admission. In the next few days the patient was managed conservatively on the lines of acute renal failure. On $10^{\text {th }}$ day of hospitalization his LDH and liver enzymes returned to normal and serum urea and creatinine were $98 \mathrm{mg} / \mathrm{dl}$ and $1.5 \mathrm{mg} / \mathrm{dl}$ respectively. Repeat USG of abdomen did not show any renal abnormalities and no histopathological investigation was carried out to determine the underlying renal injury which might have contributed to ARF. He was discharged on $11^{\text {th }}$ day of admission in a stable condition without experiencing other complications and with advice of a possible severe reaction to a subsequent sting. On follow up after 1 month the child was found to be in satisfactory good health and his serum urea and creatinine were $28 \mathrm{mg} / \mathrm{dl}$ and $0.8 \mathrm{mg} / \mathrm{dl}$ respectively.

\section{Discussion}

The medically important family of the insects order Hymenoptera are Vespidae (hornets, wasps and yellow jackets), Apidae (honey bees and bumble bees) and Formicidae (ants). Bees leave stings behind in the wound whereas wasps do not. The offending large black wasps involved in this case were identified as "Vespa polistes" and no stings were identified in the wounds of our patient. Mass sting envenomations may occur when a hive is physically disturbed by children as happened in our case ${ }^{1,2}$. Bee venom contains an aqueous solution of four primary components: mellitin, phospholopase $A 2$, hyaluronidase and mast cell degranulation protein ${ }^{3}$. Wasp venom contains a number of neurotransmitters, 
neuromodulators, and immunomodulators, including catecholamines, serotonin, tyramine, bradykinin and mastoparans (histamine- releasing factors), all of which induce pain and inflammation. Wasp venom also contains allergenic components, including phospholipase A, Phospholipase B, hyaluronidase, and antigen 5, which mediate anaphylaxis and delayed hypersensitivity reactions ${ }^{4}$. The reactions following hymenoptera stings may be grouped into large local, toxic, unusual and anaphylaxis reactions. Local reactions are the usual common phenomena after insect stings ${ }^{5}$. Our patient had multiple erythematous sting marks with subsequent dermal necrosis especially over the scalp and neck (Figure-1). These large local reactions are thought to be due to IgE mediated antibodies. Unusual reactions such as hemolysis, vasculitis, acute renal failure, neuritis, encephalitis and serum sickness are rarely reported ${ }^{2}$.

Wasp sting induced acute renal failure, though described, is an uncommon complication. Our patient had a rapidly worsening renal failure with evidence of hemolysis. The falling hematocrit, elevated LDH, reticulocytosis and fragmented $\mathrm{RBC}$ pointed towards a hemolytic process. The mechanisms postulated for renal damage due to wasp stings are: (i) direct nephrotoxicity due to toxin; (ii) hypotension leading to ischemic tubular necrosis and (iii) pigment nephropathy due to hemoglobinuria and myoglobinuria ${ }^{6}$.

In a review of previously reported 24 cases of hymenopterae sting hemolysis and rhabdomyolysis were observed in 14 out of 21 evaluated cases and 11 out of 19 evaluated cases respectively. Abnormal liver function tests were observed in almost all the evaluated cases and all the renal biopsies showed acute tubular necrosis ${ }^{7}$.

The management of massive wasp envenomation remains supportive with no specific antivenom being available. Anaphylaxis must be treated promptly with epinephrine $0.01 \mathrm{mg} / \mathrm{kg}$ IM (1:1000 aqueous solution), repeated in 10-15 minutes if clinical improvement is not apparent. Standard treatment of other symptoms of anaphylaxis, such as airway management, bronchodilators, fluids and vasopressor are indicated based on signs and symptoms. A short course of oral corticosteroid is often used to prevent late-phase allergic reactions ${ }^{8}$. Early treatment with steroids and antihistaminics which is advised in anaphylaxis were not able to prevent ensuing toxin related multisystem injury (renal, hepatic and encephalopathy) in our patient or in those reported previously ${ }^{9,10}$.

Management of the rapidly developing acute renal failure required prompt renal replacement therapy - peritoneal dialysis (PD) or hemodialysis. In our case, PD was carried out considering the patient's age and overall general condition. In addition, restricted fluid therapy, antihistaminics, diuretic and corticosteroid administration formed the main basis of treatment. Successful management of severe ARF following Africanized bee stings with repeated hemodialysis, hemofiltration or peritoneal dialysis has been discussed in many reports $7,9,10,11$. No clinical criteria or predictors identify people at potential risk for anaphylaxis or serious reactions caused by insect stings.

All patients with history of anaphylaxis should be prescribed sting kit containing preloaded syringe with epinephrine for self administration and should avoid attracting insects with sweet foods, bright colored clothes, perfumes or cosmetics. Venom immunotherapy has been shown to reduce the risk of anaphylaxis in insect sting sensitive patients with an efficacy of $95 \%$ to $97 \%{ }^{12}$. Repeated injections of purified venom produce a blocking IgG antibody response to venom. All patients with history of anaphylaxis to insect sting should undergo desensitization.

\section{Conclusion}

Though majority of those stung escape with trivial local reactions, one should be aware of uncommon serious systemic effects which may prove fatal unless appropriately managed. Such cases need to be admitted where facilities for monitoring, intensive care, and dialysis support are available, and followed up for at least 2 weeks as renal failure may be progressive and delayed. Mortality remains significant with multi system involvement, but in the majority who survive, the prognosis is good with satisfactory recovery of renal function.

\section{References}

1. Lai MW, Klein-Schwartz W, Rodgers GC, et al.2005 Annual report of the American Association of Poison Control Centres nation poisoning and exposure database. Clin Toxicol 2006;44:803-932.

2. Light WC, Reisman RE, Shimizu M, Arbesman CE. Unusual reactions following insect stings : clinical features and immunologic analysis. J Allergy Clin Immunol 1977;59:391-97.

3. Hoffman DR, Shipman WH. Allergens in the bee venom: separation and identification of the major allergens. J Allergy Clin Immunol 1976;58:551-62.

4. King TP, Spangfort MD. Structure and biology of stinging insect venom allergens. Int Arch Allergy Immunol $2000 ; 123: 99-106$. 
5. Wright DN, Lockey RF. Local reactions to stinging insects (Hymenoptera). Allergy Proc 1990;11:23-28.

6. Patil PL, Salkar HR. Wasp sting induced acute renal failure. Indian J Nephrol 2004;14: 30-31.

7. Thiruventhiran $\mathrm{T}$, Goh $\mathrm{BL}$, Leong $\mathrm{CL}$, et al. Acute renal failure following multiple wasp stings. Nephrol Dial Transplant 1999;14:214-17.

8. Brown SG, Mullins RJ, Gold MS. Anaphylaxis: diagnosis and management. Med J Aust 2006;185:283-89.
9. Bhatta N, Singh R, Sharma S, Sinha A, Raja S. Acute renal failure following multiple wasp stings. Pediatr Nephr 2005;20:1809-10.

10. Subramanian C, Jain V, Singh M, Kumar L. Allergic and systemic reactions following yellow jacket stings. Indian Pediatr 2000;37:1003-05.

11. Humvel D, Bollandard F, Hulin A. Multiple African honey bee stings and acute renal failure. Nephron 1998;78:235-36.

12. Moffitt JE, Golden DBK, Reisman RE, et al. Stinging insect hypersensitivity: a practice parameter update. J Allergy Clin Immunol 2004;11:869-96.

\section{How to cite this article?}

Kumar MK, Thakur SN. Acute Renal Failure and Seizure following Multiple Wasp Stings: A Case Report. J Nepal Paediatr Soc 2012;32(1):65-68. 